ISSN 0103-5150

Fisioter. Mov., Curitiba, v. 28, n. 2, p. 327-337, Apr./June 2015

Licenciado sob uma Licença Creative Commons DOI: http://dx.doi.org.10.1590/0103-5150.028.002.A013

\title{
Comparative study between manual therapy and TENS Burst in patients with tension-type cephalalgia
}

\section{Estudo comparativo entre a terapia manual e a TENS Burst em pacientes portadores de cefaleias tensionais}

\author{
Denise Vasconcelos Fernandes, Fhelício Sampaio Viana, Jefferson Paixão Cardoso*
}

Universidade Estadual do Sudoeste da Bahia (UESB), Jequié, BA, Brazil

\begin{abstract}
Introduction: Cephalgia or cephalalgia is one of the most common symptoms in the general population. Objective: To compare the efficacy of physical therapy modalities, through manual therapy and the effect of Transcutaneous Nerve Stimulation (TENS) for tension-type cephalalgia. Materials and methods: The study was compounded by 60 subjects, but only 40 of them completed it, due to the exclusion criteria. These were divided into control group and intervention group. The control group received treatment - manual therapy. The intervention group received TENS Burst. Patients underwent ten sessions of treatment, made at every two days on a week, lasting 30 minutes each session. Results: The characteristics related to lifestyle, postural issues and range of motion are responsible for the main causes of tension-type cephalalgia. Discussion: treatments showed effective results in all cases in relation to pain intensity, but the use of manual therapy
\end{abstract}

* DVF: Grad., e-mail: iseffisio@hotmail.com FSV: Grad., e-mail: fhelicio@hotmail.com JPC: MSc, e-mail: jpcardoso@uesb.edu.br 
techniques give the patient a better quality of life compared to the use of TENS. Final considerations: The treatment of this condition deserves analysis and studies; however, there are only a few studying physical therapy techniques, especially regarding to the use of TENS.

Keywords: Tension-type cephalalgia. Physical therapy modalities. Transcutaneous electric nerve stimulation.

\section{Resumo}

Introdução: Cefaleia ou dor de cabeça é um dos sintomas mais comuns na população em geral. Objetivo: Comparar a eficácia de modalidades de fisioterapia - terapia manual e estimulação nervosa transcutânea (TENS) - para cefaleia do tipo tensional. Materiais e métodos: 0 estudo foi composto inicialmente por 60 indivíduos, mas apenas 40 completaram-no em virtude dos critérios de exclusão. Estes foram divididos em grupo controle e grupo de intervenção. O grupo controle recebeu terapia manual e o grupo de intervenção recebeu TENS. Os pacientes foram submetidos a 10 sessões de tratamento, sendo estas feitas dois dias por semana, com duração de 30 minutos cada. Resultados: As características relacionadas ao estilo de vida, problemas posturais e amplitude de movimento são responsáveis pelas principais causas de dor de cabeça de tensão. Discussão: Os tratamentos foram eficazes em todos os casos em relação à intensidade de dor, mas a utilização de técnicas de terapia manual deu aos pacientes uma melhor qualidade de vida, em comparação com a utilização de TENS. Considerações finais: $O$ tratamento dessa condição merece análise e estudos, no entanto, há poucos estudos científicos que estudam técnicas de fisioterapia, especialmente com relação ao uso da TENS.

Palavras-chave: Cefaleia do tipo tensional. Modalidades de fisioterapia. Estimulação elétrica nervosa transcutânea.

\section{Introduction}

Cephalalgia is the term used to designate all sorts of pains located on the head. It is one of the most common causes of pain on adults and one of the most disabling ones in Brazil $(1,2,3)$.

The cephalalgias may be primaries or secondaries, according to the aetiology (4). The tension-type one, which is a primary kind, inheres in the most common variant of all kinds of cephalalgia, affecting a substantial part of the general population (5). This kind of cephalalgia is known as tension, due to the muscular contraction (3).

It is classically featured as pain on constrictive character, usually bilateral, with mild to moderate, not aggravated by daily routine physical activities and during between thirty minutes and seven days. It may be ranked in episodic, when occurring on less than 180 days per year and 15 days per month. Alternatively, it also may be chronical, when its frequency equals or overcomes these rates (15 days a month), for at least three months $(6,7,8)$.
The unenviable accumulation of certain metabolic, concomitant with one's life style and emotional state of mind brings on symptoms resulting to tension-type cephalalgias. Therefore, the praxis of manual therapy due to its effects on one's structure also supports on the cephalalgia's alleviation, diminishing such symptomatology (5).

Likewise, the Transcutaneous Electric Stimulation (TENS) has been mentioned on the literature as a pain control alternative. It is a non-pharmacological therapy, non-invasive, accessible, easily manipulating, and with a very few recommendations against usage. Its procedures work through endogenous opiates liberations $(9,10)$.

TENS on Burst modulation provides a group of several stimulus, felt by the patient as an only one. This sort of TENS is characterised by having high wave bringer, modulated by low frequency pulsing ( 1 to $4 \mathrm{~Hz}$ ) and duration varying between 200 to $300 \mu \mathrm{s}$. Low frequencies are recommended in chronical conditions, bestowing on pain relief $(11,12,13)$. 
Physiotherapeutic intervention through manual therapy and TENS Burst may offer tension-type cephalalgia relief benefits. Ergo, scientific studies on physiotherapy field of such treatment will permit further enlightenments and provide better assistance to these carrier conditions.

This study aimed to compare the physioterapeutical treatments through manual therapy on tensiontype cephalalgias with TENS Burst effect.

\section{Materials and methods}

On Southwest State University of Bahia Physiotherapy Teaching Clinic [Clínica Escola de Fisioterapia da Universidade Estadual do Sudoeste da Bahia], located on Jequié (BA), an interventionist and quantitative analytical approach study was accomplished. The data were collected between 2010 October and December.

On the specimen group were included 60 people with voluntary interest. Such ones went through a triage, made by a physioterapeutical evaluative application, requesting socio demographic characteristics, subject's lifestyle, posture and clinical movement variable amplitude, and pain related clinical variable. Those figures were analysed based on Cephalalgia International Society same criteria, being admitted subjects with chronical characteristics' tension-type cephalalgia. The study exclusion principles were subjects with other sorts of cephalalgia, and those who not attended it for until three times in a role.

After the subjects' identification and selection, they were allocated through simple randomly process in control group and intervention group. The control group subjects received treatment through manual therapy techniques'. As for the intervention group, the used treatment was transcutaneous electric stimulation on Burst modulation - TENS Burst. The subjects were subordinated to ten sections of treatment, at each two days of the week, during about 30 minutes each. At the end of the treatment, a new evaluation was performed, using the same admissional evaluative application.

The physioterapeutical treatment protocol for manual therapy was grounded on literature purposes, and used on the control group with: myofascial cervical manoeuvre and cranial applied manual manoeuvre, global pompage, sciatic and mediano sinew's mobilization, cervical spine stabilization strengthening through co-contraction exercises and Kabat, cervical segment articular mobilization, and stretching techniques. As for the transcutaneous electric stimulation - TENS - protocol, to the intervention group, it was made accordingly to the literature guidelines that seek analgesia, being: TENS on Burst modulation, 230 microseconds pulse and $4 \mathrm{~Hz}$ wrapper frequency.

It was realised the study's population characterization on the control and intervention groups, and made the descriptive statistics using absolute and relative frequency to categorical variables and central tendency measurements (amplitude, average and standard-diversion) to continuum variables. The association between the intragroup variations was measured using the Pearson and Wilcoxon Quisquare test. To the evaluation between groups was conditioned by the Mann-Whitney test. It was used $5 \%$ of as significative statistics measurement on all tests. EpiData, version 1.5 and SPSS, version 15 were used.

The present research was approved by the Southwest State University of Bahia Research and Ethic Committee, accordingly to 196/96 Resolution, opinion No. 156/2010.

\section{Results}

Forty subjects concluded the study, twenty volunteers excluded for presenting another sorts of cephalalgias or due to missing three consecutive intervention days. Therefore, the control and intervention groups were composed by twenty patients each, being $87.5 \%(\mathrm{n}=35)$ were females and $12.5 \%$ $(n=5)$ were male.

On Table 1 presents socio demographic characteristics. It was observed that the age of the subjects drifted between 18 and 80 (33.30 \pm 15.03$)$. In addition, $62.5 \%$ were single; $35.0 \%$ married; $10.0 \%$ lived by themselves; $27.5 \%$ had children; $95.0 \%$ had corporal dominance on the right side. As for schooling only $10 \%$ concluding elementary school, while $65.0 \%$ are attending or had already concluded tertiary education. It was noticed that $57.5 \%$ ( $\mathrm{n}=$ 23) asserted not had any sort of previous treatment to cephalalgia. 
Table 1 - Subjects' sociodemographic characteristics treated with TENS and manual therapy

\begin{tabular}{|c|c|c|}
\hline Variables & $\mathrm{n}$ & $\%$ \\
\hline \multicolumn{3}{|l|}{ Gender } \\
\hline Female & 35 & 87.5 \\
\hline Male & 5 & 12.5 \\
\hline \multicolumn{3}{|l|}{ Marital Status } \\
\hline Single & 25 & 62.5 \\
\hline Married & 14 & 35.0 \\
\hline Divorced & 1 & 2.5 \\
\hline \multicolumn{3}{|l|}{ Schooling } \\
\hline Elementary School & 4 & 10.0 \\
\hline High School & 10 & 25.0 \\
\hline Tertiary Education & 26 & 65.0 \\
\hline \multicolumn{3}{|c|}{ Familial Arrangements } \\
\hline Live by oneself & 4 & 10.0 \\
\hline Live with a spouse & 7 & 17.5 \\
\hline $\begin{array}{l}\text { Live with spouse and } \\
\text { grandchildren }\end{array}$ & 6 & 15.0 \\
\hline Other arrangements & 23 & 57.5 \\
\hline \multicolumn{3}{|l|}{ Offspring } \\
\hline Yes & 11 & 27.5 \\
\hline No & 29 & 72.5 \\
\hline \multicolumn{3}{|l|}{ Dominance } \\
\hline Right & 38 & 95.0 \\
\hline Left & 2 & 5.0 \\
\hline \multicolumn{3}{|l|}{ Previous Treatment } \\
\hline No & 23 & 57.5 \\
\hline Yes & 17 & 42.5 \\
\hline
\end{tabular}

As for lifestyle (Table 2), it could be verified that $25.0 \%$ of the subjects affirmed to have inadequate nourishment; $70.0 \%$ of them denied elitism; none of them claimed to be a smoker. The usage of inadequate mattress corresponded to $42.5 \%$ of subjects who also asserted to use low pillows $(27.5 \%)$ and high (15.0\%). Most of the subjects (67.5\%) did not practice any sort of physical activity.

The comparison between TENS and manual therapy was observed from movement and posture variable clinical amplitude on (Table 3). Concerning to the positioning of the head, it was noticed that twelve subjects $(60.0 \%)$ presented preceding before
Table 2 - Characteristics of subject's treated with TENS and manual therapy lifestyle

\begin{tabular}{lcc}
\hline Variables & $\mathbf{n}$ & $\%$ \\
\hline Nourishment Habits & 30 & 75.0 \\
Adequate & 10 & 25.0 \\
Inadequate & & \\
Elitism & 28 & 70.0 \\
No & 12 & 30.0 \\
Yes & & \\
Smoking & 0 & 0.0 \\
Yes & 40 & 100.0 \\
No & & \\
Mattress & 23 & 57.5 \\
Adequate & 17 & 42.5 \\
Inadequate & & \\
Pillow & 11 & 27.5 \\
Low & 6 & 15.0 \\
High & 20 & 50.0 \\
Medium & 3 & 7.5 \\
Do not use & & \\
Physical Activity Practicing & 13 & 32.5 \\
Yes & 27 & 67.5 \\
No & & \\
\hline
\end{tabular}

TENS treatment, and $66.0 \%$ after treatment. To the manual therapy, $60.0 \%$ before the treatment as well had preceding, and after the therapy, there were $30.0 \%(p=0.059)$ decreasing. It was perceived that $65.0 \%(\mathrm{n}=13)$ of the subjects presented neck normal positioning before TENS treatment and $70.0 \%(\mathrm{n}=14)$ after it. To the manual therapy group, before the treatment $75.0 \%(n=15)$ presented normal positioning and after therapy the normally of the positioning increased $100.0 \%(p=0.014)$.

Examining the subject' shoulder symmetry treated on TENS group, $25.0 \%(n=5)$ were symmetric before the treatment and, after that, the number inconspicuously increased $30.0 \%$. On manual therapy group, the lesser part of the subjects $(10.0 \%)$ presented symmetric shoulders, and after the therapy, this index significantly increased to $85.0 \%(\mathrm{p}<0.001)$. The touching of the vertebral and cervical segments, and the scapular and cervical waistline musculature, $90.0 \%(n=18)$ of the TENS group subject's referred 
to pain before the treatment and after it there was $40.0 \%$ decreasing. On Manual Therapy group, most of subjects $(80.0 \%)$ referred to touching pain before treatment and after that, none of them alluded painful sensation $(\mathrm{p}<0.001)$.

As for the amplitude of movement (ADM) on TENS group flexion before the therapy, it was verified incomplete amplitude on three subjects (15.0\%), and after treatment, only one subject $(5.0 \%)$ remained with incomplete ADM. On Manual Therapy group before the therapy was validated incomplete amplitude on only five subjects (25.0\%), and after treatment, no one remained with the condition ( $p=0.008)$. To ADM in extension, on TENS group before therapy was verified incomplete amplitude on $30.0 \%(n=6)$ of the subjects, and after treatment, only $15.0 \%(n=3)$ remained with incomplete ADM. On manual therapy group before therapy was verified incomplete amplitude on $35.0 \%$ $(\mathrm{n}=7$ ) subjects, and after treatment, only one subject $(5.0 \%)$ remained with incomplete ADM ( $p=0.007)$.

For right slope on ADM, on TENS group before therapy was validated incomplete amplitude on over half of the subjects $55.0 \%$ and there was no changes after treatment. On manual therapy group was noticed incomplete amplitude on $50.0 \%(n=10)$ of the subjects before treatment, and after it, there was $25.0 \%(n=5)(p=0.132)$ decreasing. To left slope, on TENS group before therapy was verified incomplete amplitude on twelve $(60.0 \%)$ of the subjects, and after treatment there was slightly reduction of this percentage (55.0\%). For the same ADM on manual therapy group, before treatment, it could be observed incomplete amplitude on twelve patients $(60.0 \%)$, and after treatment only $25.0 \%(\mathrm{n}=5)$ remained with incomplete ADM ( $\mathrm{p}=0.021)$

Concerning to right rotation on ADM, on TENS group before therapy was verified incomplete amplitude on $35.0 \%$ ( $n=7$ ) of the subjects, and after treatment there was $30.0 \%$ feeble decreasing. On manual therapy before treatment was noticed incomplete amplitude on right rotation on seven subjects (35.0\%), and after that, four $(20.0 \%)$ remained with incomplete ADM ( $p=0.157)$. For left rotation on ADM, on TENS group before therapy was observed incomplete amplitude on $35.0 \%(n=7)$ of the subjects, and after treatment there was paltry decrease to $30.0 \%$. On manual therapy group before therapy was verified incomplete amplitude on left rotation on $35.0 \%$ ( $n=7$ ) of the subjects, and after treatment $20.0 \%$ $(\mathrm{n}=4)$ remained with incomplete ADM ( $\mathrm{p}=0.157)$.

Table 3 - Comparison between TENS and manual therapy accordingly posture and clinical movement variable amplitude

\begin{tabular}{|c|c|c|c|c|c|c|c|c|c|}
\hline \multirow[t]{3}{*}{ Variables } & \multicolumn{4}{|c|}{ Before } & \multicolumn{4}{|c|}{ After } & \multirow[t]{2}{*}{$\mathrm{p}$} \\
\hline & \multicolumn{2}{|c|}{ TENS } & \multicolumn{2}{|c|}{ Manual therapy } & \multicolumn{2}{|c|}{ TENS } & \multicolumn{2}{|c|}{ Manual therapy } & \\
\hline & $\mathrm{n}$ & $\%$ & $\mathrm{n}$ & $\%$ & $\mathrm{n}$ & $\%$ & $\mathrm{n}$ & $\%$ & \\
\hline \multicolumn{10}{|l|}{ Head } \\
\hline Normal & 8 & 40.0 & 8 & 40.0 & 7 & 35.0 & 14 & 70.0 & 0.059 \\
\hline Preceding & 12 & 60.0 & 12 & 60.0 & 13 & 65.0 & 6 & 30.0 & \\
\hline \multicolumn{10}{|l|}{ Neck } \\
\hline Normal & 13 & 65.0 & 15 & 75.0 & 14 & 70.0 & 20 & 100.0 & \\
\hline Preceding & 1 & 5.0 & 0 & 0.0 & 1 & 5.0 & 0 & 0.0 & 0.014 \\
\hline Hiperlordosis & 6 & 30.0 & 5 & 25.0 & 5 & 25.0 & 0 & 0.0 & \\
\hline \multicolumn{10}{|l|}{ Shoulder } \\
\hline Symmetric & 5 & 25.0 & 2 & 10.0 & 6 & 30.0 & 17 & 85.0 & $<0.001$ \\
\hline Asymmetric & 15 & 75.0 & 18 & 90.0 & 14 & 70.0 & 3 & 15.0 & \\
\hline \multicolumn{10}{|l|}{ Touching } \\
\hline Pain & 18 & 90.0 & 16 & 80.0 & 8 & 40.0 & 0 & 0.0 & $<0.001$ \\
\hline Painless & 2 & 10.0 & 4 & 20.0 & 12 & 60.0 & 20.0 & 100.0 & \\
\hline \multicolumn{10}{|l|}{ Flexion $^{\dagger}$} \\
\hline Complete ADM & 17 & 85.0 & 15.0 & 75.0 & 19 & 95.0 & 20 & 100.0 & 0.008 \\
\hline
\end{tabular}


Table 3 - Comparison between TENS and manual therapy accordingly posture and clinical movement variable amplitude

\begin{tabular}{|c|c|c|c|c|c|c|c|c|c|}
\hline \multirow[t]{3}{*}{ Variables } & \multicolumn{4}{|c|}{ Before } & \multicolumn{4}{|c|}{ After } & \multirow[t]{3}{*}{ p } \\
\hline & \multicolumn{2}{|c|}{ TENS } & \multicolumn{2}{|c|}{ Manual therapy } & \multicolumn{2}{|c|}{ TENS } & \multicolumn{2}{|c|}{ Manual therapy } & \\
\hline & $n$ & $\%$ & $\mathbf{n}$ & $\%$ & $\mathbf{n}$ & $\%$ & $\mathrm{n}$ & $\%$ & \\
\hline Incomplete ADM & 3 & 15.0 & 5.0 & 25.0 & 1 & 5.0 & 0 & 0.0 & \\
\hline \multicolumn{10}{|l|}{ Extension ${ }^{\dagger}$} \\
\hline Complete ADM & 14 & 70.0 & 13 & 65.0 & 17 & 85.0 & 19 & 95.0 & 0.007 \\
\hline Incomplete ADM & 6 & 30.0 & 7 & 35.0 & 3 & 15.0 & 1 & 5.0 & \\
\hline \multicolumn{10}{|l|}{ Right Slope } \\
\hline Complete & 9 & 45.0 & 10 & 50.0 & 9 & 45.0 & 15 & 75.0 & 0.132 \\
\hline Incomplete & 11 & 55.0 & 10 & 50.0 & 11 & 55.0 & 5 & 25.0 & \\
\hline \multicolumn{10}{|l|}{ Left Slope } \\
\hline Complete & 8 & 40.0 & 8 & 40.0 & 9 & 45.0 & 15 & 75.0 & 0.021 \\
\hline Incomplete & 12 & 60.0 & 12 & 60.0 & 11 & 55.0 & 5 & 25.0 & \\
\hline \multicolumn{10}{|l|}{ Right Rotation ${ }^{\dagger}$} \\
\hline Complete ADM & 13 & 65.0 & 13 & 65.0 & 14 & 70.0 & 16 & 80.0 & 0.157 \\
\hline Incomplete ADM & 7 & 35.0 & 7 & 35.0 & 6 & 30.0 & 4 & 20.0 & \\
\hline Left Rotation ${ }^{\dagger}$ & & & & & & & & & 0.157 \\
\hline Complete ADM & 13 & 65.0 & 13 & 65.0 & 14 & 70.0 & 16 & 80.0 & \\
\hline Incomplete ADM & 7 & 35.0 & 7 & 35.0 & 6 & 30.0 & 4 & 20.0 & \\
\hline
\end{tabular}

Note: $\mathrm{p}=$ statistical significance value $(\mathrm{p}<0.05) ;{ }^{\dagger} \mathrm{ADM}=$ amplitude of movement.

Table 4 presents the comparison results between TENS and manual therapy for pain related clinical variable. It points out that the pain stage on TENS group' subjects before treatment prevailed on chronical and chronical with high exacerbation category, with $20.0 \%(n=4)$ and $70.0 \%(n=14)$ respectively, and, afterwards, $90.0 \%(\mathrm{n}=18)$ it fit only in the chronical with high exacerbation category. The manual therapy subjects that fit on chronical stage before treatment were seven (35.0\%) and on chronical with high exacerbation category, thirteen (65.0\%), after that, most of the subjects $(90.0 \%)$ fit on it $(\mathrm{p}<0.001)$.

As for the TENS group pain location, before treatment, all subjects (100.0\%) detailed that cephalalgia was presented bilaterally, and after therapy, such index remained. On manual therapy group $80.0 \%(n=16)$ reported bilateral pain before treatment, being the index decreased $45.0 \%(p=0.008)$ thereafter. Moreover, on TENS group, thirteen subjects $(65.0 \%)$ presented pain as helmet before treatment, and after it twelve subjects $(60.0 \%)$ claimed when they felt pain, it was still as helmet. On the other hand, before treatment, on manual therapy, most of the subjects $(90.0 \%)$ related pain as helmet, and after so, when there was such pain, it decreased to $50.0 \%(\mathrm{p}=0.006)$.

Considering how often pain occur, $55.0 \%(n=11)$ and $30.0 \%(n=6)$ related it happened from 10 to 15 days on a month, every day of the week, respectively, on TENS group before treatment, and after it, $65.0 \%(n=13)$ of the subjects presented varying between 2 and 4 days on a week. No one else related feeling pain every day of the week ( $p>0.005)$. Before treatment on manual therapy group, 55.0\% $(\mathrm{n}=11)$ and $30.0 \%(\mathrm{n}=6)$ related pain between 10 to 15 days on a month and every day of the week, respectively. After treatment, most of the subjects (95.0\%) mentioned pain, varying between 2 and 
4 days on a week $(\mathrm{p}=0.670)$. On manual therapy group, before treatment, $55.0 \%(\mathrm{n}=11)$ and $30.0 \%$ $(\mathrm{n}=6)$ informed of pain from 10 to 15 days on the month and every day of the week, respectively. After treatment, the most of the subjects (95.0\%) stated pain, varying between 2 and 4 days on a week $(\mathrm{p}=0.670)$.
The complaining about pain irradiation or paraesthesia on TENS group was not present on $55.0 \%$ of the subjects, and such index increased $70.0 \%(\mathrm{n}=14)$ after therapy. On manual therapy $75.0 \%(n=15)$ denied pain irradiation or paraesthesia before treatment, and none of the subjects reported such complains anymore afterwards $(\mathrm{p}=0.30)$.

Table 4 - Comparison between TENS and Manual Therapy accordingly pain related clinical variables

\begin{tabular}{|c|c|c|c|c|c|c|c|c|c|}
\hline \multirow{3}{*}{ Variables } & \multicolumn{4}{|c|}{ Before } & \multicolumn{4}{|c|}{ After } & \multirow[t]{3}{*}{$\mathrm{p}$} \\
\hline & \multicolumn{2}{|c|}{ TENS } & \multicolumn{2}{|c|}{ Manual therapy } & \multicolumn{2}{|c|}{ TENS } & \multicolumn{2}{|c|}{ Manual therapy } & \\
\hline & $n$ & $\%$ & $\mathrm{n}$ & $\%$ & $n$ & $\%$ & $n$ & $\%$ & \\
\hline \multicolumn{10}{|l|}{ Stage } \\
\hline Acute & 1 & 5.0 & 0 & 0.0 & 0 & 0.0 & 0 & 0.0 & $<0.001$ \\
\hline Sub-acute & 1 & 5.0 & 0 & 0.0 & 2 & 10.0 & 0 & 0.0 & \\
\hline Chronical & 4 & 20.0 & 7 & 35.0 & 0 & 0.0 & 1 & 5.0 & \\
\hline $\begin{array}{l}\text { Chronical with acute } \\
\text { exacerbation }\end{array}$ & 14 & 70.0 & 13 & 65.0 & 18 & 90.0 & 19 & 95.0 & \\
\hline \multicolumn{10}{|l|}{ Pain Laterality } \\
\hline Bilateral & 20 & 100.0 & 16 & 80.0 & 20 & 100.0 & 9 & 45.0 & 0.008 \\
\hline Unilateral & 0 & 0.0 & 4 & 20.0 & 0 & 0.0 & 11 & 55.0 & \\
\hline \multicolumn{10}{|l|}{ Pain Specific Region } \\
\hline Frontal & 1 & 5.0 & 0 & 0.0 & 2 & 10.0 & 7 & 35.0 & 0.006 \\
\hline Temporal & 4 & 20.0 & 1 & 5.0 & 4 & 20.0 & 1 & 5.0 & \\
\hline Occipital & 2 & 10.0 & 0 & 0.0 & 2 & 10.0 & 0 & 0.0 & \\
\hline As a Helmet & 13 & 65.0 & 18 & 90.0 & 12 & 60.0 & 10 & 50.0 & \\
\hline Without Accurate Location & 0 & 0.0 & 1 & 5.0 & 0 & 0.0 & 2 & 10.0 & \\
\hline \multicolumn{10}{|l|}{ Frequency } \\
\hline Every day of the week & 6 & 30.0 & 6 & 30.0 & 0 & 0.0 & 0 & 0.0 & 0.670 \\
\hline 2 a 4 days on a week & 7 & 35.0 & 3 & 15.0 & 13 & 65.0 & 19 & 95.0 & \\
\hline 10 a 15 days on a month & 7 & 35.00 & 11 & 55.0 & 7 & 35.0 & 1 & 5.0 & \\
\hline \multicolumn{10}{|l|}{ Irradiation } \\
\hline Negative & 11 & 55.0 & 15 & 75.0 & 14 & 70.0 & 20 & 100.0 & 0.030 \\
\hline MSD & 1 & 5.0 & 3 & 15.0 & 1 & 5.0 & 0 & 0.0 & \\
\hline MSE & 1 & 5.0 & 0 & 0.0 & 0 & 0.0 & 0 & 0.0 & \\
\hline Others & 7 & 35.0 & 2 & 10.0 & 5 & 25.0 & 0 & 0.0 & \\
\hline
\end{tabular}

Note: $\mathrm{p}=$ statistical significance value $(\mathrm{p}<0.05)$. 


\section{Discussion}

Tension-type cephalalgias are considered those which most prevalence on human beings. Its annual currency is between $70.0 \%$ and $90.0 \%(14,15)$.

Our study demonstrated cephalalgia high incidence on females, corroborating with stablished literature that points out women fell more recurrent pain than men, including cephalalgias. Such occurrence might be related to oestrogen hormones and progesterone, which increases stress response, besides other elements not here enlisted (16).

Stress can lead to muscular contracting and functional alterations (17). This muscular alteration and, consequently, muscular sensitivity is significantly heightened as much as on those days the subjects experience cephalalgia, as on those days it does not (18). Likewise, such deed was present in these subjects.

Concerning to schooling, it could be perceived that as higher the level, more overloaded the subjects were. Nevertheless, it must be considered that high-educated subjects have more appliances of understanding the disease process, as well as to the importance of some adjustments on lifestyle that might aid on facing tension-type cephalalgia (19).

The constant changing on activity, thereby bodily orientation, also can steer to overload and painful spots and squeezed sensations appearances. In addition, this study substantiate that the inadequate usage of mattresses and pillows, and bodily domination overburden one side of the body, interfered on corporal mechanics, posture and movement, predisposing the subjects to several tension or trigger points major appearances.

Studies have been vouched the tension-type cephalalgias occurring to the trigger points found on sub occipitals muscles, superior trapezoid, temporal and sternocleidomastoid, besides influencing shoulder musculature and paravertebral (20). These assumptions assert that the referred pain caused by those muscles bestow to tension-type cephalalgia's characteristics. This is the only brand that indicates scientific evidences on sustaining some possible etiological function to muscular trigger points (21).

Shoulders inadequate alignment is a frequent alteration, which begets spine misalignment. Inadequate postural habits awards to such situation. The needing of maintaining a bi pupillary horizontal line results on shoulders and neck detour, provoking cervical muscles major struggle, particularly from sternocleidomastoid and trapezoid ones (17). Such characteristic was found on tension-type cephalalgia subjects that partook the study.

The increasing of pericranial painful sensation detected by manual touching is the most significative deviant finding on subjects with tension-type cephalalgia. The painful sensation increases according to cephalalgia's intensity and frequency, and enhances even more during crisis. The pericranial pain is easily researched through manual touching during clinical examination, and presents as a useful guide to diagnosis and treatment strategy (22).

Cephalalgia laterality is an important aspect to its diagnosis either. It has been revealed bilateral on over $80.0 \%$ of the cases, and the posterior regions of the head and neck are the most embroiled ones (8). Varjão at al. (23) chronicles that bilaterality is present on $90.0 \%$ of the cases. On this study, $100.0 \%$ and $80.0 \%$ of the subjects allocated on TENS group and on Manual Therapy group, respectively, presented the same correlation as literature.

As for lifestyle, authors have stated that it cannot be noticed any relation between physical activity practicing and scenery improvement, although it is known that aerobic exercises increase endogenous endorphin's levels, ameliorate tissue oxygenation and vascularization, easing algogenic substances removal $(19,23)$.

Representative United States of America (EUA) and United Kingdom population specimen have demonstrated that only half of the cephalalgia's diagnosed people had been attended by a physician. Notwithstanding, over $80.0 \%$ of tension-type cephalalgia's carriers on Denmark had never been attended by a cephalalgia's physician (24).

Low medical appointments rate on developed countries can indicate that many cephalalgia's carriers are not aware of effective treatment existence. It is unlikable there is a better situation where the resources are proportionally limited (24). This could be testified on our study, as the majority of the subjects (57.5\%) asserted never had done or sought any kind of previous treatment.

Regarding the sorts of treatments, it was observed that there are several sets of techniques, specific literature repots, such as electrotherapy, acupuncture, cervical traction, kinesis therapy and treatments constituted by stretching, muscular relaxation and vertebral mobilization (4). 
The usage of physical means, as transcutaneous electric stimulation, acupuncture or refrigerant steam local application on trigger points are also mentioned as solution to painful situation, throughout muscular distention and trigger points inactivity (25).

Transcutaneous electric stimulation (TENS) is described as specific electrotherapeutic technique on pain control. It works on muscular spasm reduction and on muscular throe inhibition, offering lasting benefits, besides being used as prophylaxis, divesting one from cephalalgias and medicine excessive use (26).

On a study developed by Bezerra and Lucena (27), the usage of transcutaneous electric neural stimulation (TENS) on "Burst" modulation was used as co-operator on tension-type cephalalgia treatment. As studying TENS effect on tension-type cephalalgia, the authors substantiated that all subjects were granted by TENS using, as well as on the present study. Nevertheless, on our study, as we analysed the variations that indicated amplitude of movement and postural aspects. The subjects treated with TENS, did not present significative changes on these features after treatment, mainly because in this study were not accomplished co-interventions, such as: medications, therapies or behaving, postural orientation and self-stretching teaching lessons, if not the aim of this study, as our main goal was overridingly assess the therapeutic resources on pain relation efficacy.

Cephalalgias' treatment by manual methods have recently receives major attention on literature and clinical praxis (28). Mobility exercises may be applied, seeking amplitude of movement (ADM) improvements or to segmental mobility restrictions, specific muscular stretching, and soft tissues manipulations, particularly to superior cervical extensors. As a result, it settles myofascial restrictions and trigger points that may be contributing to cephalalgia, further considering neural system mobilization movements and interfacing structures.

On Morelli and Rebelatto (5) study, the subjects were submitted to a treatment consisted by ten manual cervical traction sections, stretching, vertebral mobilization and massages, with curves indicating pin intensity decreasing along the way. Basing on such protocol and on others literature chronicles, the manual therapy applied treatment also demonstrated cephalalgia alleviation efficacy. Accordingly, this method treatment was effective on cephalalgia and muscular tension relief on the observed data, with touching, postural aspects, and amplitude of movement significative changes on the subjects treated on this group.

On the group treated with TENS on Burst modulation, our study verified over $50.0 \%$ decreasing on pain complaints to muscular and vertebral touching, corroborating this resource efficacy. Notwithstanding, the obtained data on Manual Therapy group indicated this technique was best used on these complaints solving, as $100.0 \%$ of the subjects did not refer to any pain after treatment.

A study made by Jay et al. (29) analyses physiotherapy treated groups' responses, including TENS, only TENS and a group treated without physiotherapy nor TENS. The author pointed out that the cephalalgia intensity decreases hastily and significantly if used treatment alongside with physiotherapy. He concludes by saying the most effective treatment is the one which interlocks physiotherapy and TENS on treating tension-type cephalalgia.

On this study we supported the two resources used separately (manual therapy and TENS on Burst modulation) have beneficial effects on tension-type cephalalgia carrier subjects. Nonetheless, manual therapy proved more effective results on them, as it clashes on the causes, mechanics mostly, of pain, and not only on painful sensation feeling, as happens on electric stimulation with TENS.

\section{Final Considerations}

With this work, it could be noticed that the practicing of physiotherapy, particularly on this research, about TENS and manual therapy usage as alternative on tension-type cephalalgia treatment, conveys great benefits to the subjects. Although the treatments had been presented effective on concerning to the intensity of the pain, the using of manual therapy techniques award the subject major life quality, comparing to TENS Burst's.

This condition treatment deserves analysis and studying. Nevertheless, a few scientific works mind pondering on physiotherapeutic techniques, especially on concerning about TENS ones'. Besides, there would be of great value studies that expose and verify the treatment effectiveness, after it is finished, on short, medium and long terms.

Long terms conducted trials are necessary to provide major evidences about tension-type cephalalgia 
physiotherapeutic treatment. The achievement of a pilot study to select characteristics that presents the specimen as much homogeneous as possible would be necessary, but it was not possible to do so in this study, as the initial purpose was to compare two treatments on general population and consolidate the external validity of it.

A clinical trial might have a lesser dimension and duration if include characters with major tendency to present major therapeutic benefits. This would vindicate the specimen choice used methods on the present study, taking into consideration the main factors, chronicled by literature, that steer people to develop tension-type cephalalgia, using an evaluation form to admitting researching subjects (30).

\section{References}

1. Teixeira MJ, Pimenta CAM. Avaliação do doente com dor. In: Teixeira MJ, Figueró JAB. Dor: epidemiologia, fisiopatologia, avaliação, síndromes dolorosas e tratamento. São Paulo: Moreira Junior; 2001. p. 8-13.

2. Vincent M, Rodrigues AJ, Oliveira GV, Souza KF, Doi LM, Rocha MBL, et al. Prevalência e custos indiretos das cefaleias de uma empresa brasileira. Arq Neuropsiquiatr. 1998;56(4):734-43

3. Petersen CS, Nunes MLT. Cefaleia tensional crônica e psicopatologia. Psic. 2002;3(2):30-43.

4. Gherpelli JLD. Tratamento das cefaleias. J Pediatr. 2002;78(Supl.1):S3-8.

5. Morelli JGS, Rebelatto JR. A eficácia da terapia manual em indivíduos cefaleicos portadores e não portadores de degeneração cervical: análise de seis casos. Rev Bras Fisioter. 2007;11(4):325-9.

6. Matta APC, Moreira Filho PF. Sintomas depressivos e ansiedade em pacientes com cefaleia do tipo tensional crônica e episódica. Arq Neuro-Psiquiatr. 2003;61(4):991-4.

7. Matta APC, Moreira Filho PF. Cefaleia do tipo tensional: análise clínica de 50 pacientes. Arq NeuroPsiquiatr. 2006;64(1):95-9.

8. Jevoux CC, Moreira Filho PF, Souza JA. Cefaleia crônica diária primária: características clínicas. Arq NeuroPsiquiatr. 1998;56(1):64-8.
9. Pena R, Barbosa LA, Ishikawa NM. Estimulação elétrica transcutanea do nervo (TENS) na dor oncológica: uma revisão de literatura. Rev Bras Cancerol. 2008;54(2):193-9.

10. Radhakrishnan R, Sluka KA. Deep tissue afferents, but not cutaneous afferents, mediate transcutaneous electrical nerve stimulation-induced antihyperalgesia. J Pain. 2005;6(10):673-80.

11. Starkey C. Recursos terapêuticos em fisioterapia. São Paulo: Manole; 2001.

12. John OB. Estimulação elétrica nervosa transcutânea para o controle da dor. In: Nelson RM, Hayes KW, Currier DP. Eletroterapia clínica. São Paulo: Manole; 2003. p. 291-342.

13. Kahn J. Princípios e prática de eletroterapia. 4. ed. São Paulo: Livraria Santos; 2001.

14. Schwartz BS, Stewart WF, Simon D, Lipton RB. Epidemiology of tension-type headache. JAMA. 1998;279(5):81-3.

15. Bigal ME, Bordini CA, Speciali JG. Tratamento da cefaleia em uma unidade de emergência da cidade de Ribeirão Preto. Arq. Neuro-Psiquiatr. 1999;57(3B):813-9.

16. Bernardi MT, Bussadori SK, Fernandes KPS, Gonzalez DAB. Correlação entre estresse e cefaléia tensional. Fisioter Mov. 2008;21(1):87-93.

17. Carvalho DS. Síndrome da cefaleia cervicogênica. Rev Neurociências. 2001;9(2):57-9.

18. Ashina M, Bendtsen L, Jensen R, Sakai F, Olesen J. Measurement of muscle hardness: a methodological study. Cephalalgia. 1998;18(2):106-11

19. Giona P. Abordagem fisioterapêutica nas cefaléias tensionais através da terapia manual: Cascavel: Unioeste; 2003.

20. Fernandez-de-las-Peñas C, Cuadrado ML, Arendt-Nielsen L, Simons DG, Pareja JA. Myofascial trigger points and sensibilization: an update pain model for tension type headache. Cephalalgia. 2007;27(5):383-93.

21. Baracat PJF. Prevalência dos trigger points suturais nas cefaléias tipo tensional. Perspectivas. 2011 [cited 2015, May 28];5(17). Available from: http:// www.seer.perspectivasonline.com.br/index.php/ revista_antiga/article/view/489/404 
22. Subcomitê de Classificação das Cefaléias da Sociedade Internacional de Cefaléia. Classificação Internacional das Cefaleias. Trad. Sociedade Brasileira de Cefaleia. 2. ed. rev. ampl. São Paulo: Alaúde Editorial; 2006.

23. Varjão FM, Jorge JH, Nepelenbroek KH, de Alencar Júnior FGP. Cefaleia, tipo tensional. Saud Pesq. 2008;1(2):185-91.

24. World Health Organization. Atlas of headache disorders and resources in the world: 2011. Geneva: World Health Organization; 2011.

25. Teixeira MJ, Yeng LT, Altieri CE, Saito M. Cefaleia de origem cervical. Rev Med (São Paulo). 2001;80(ed. esp. pt. 2):297-306.

26. Melo AM, Neto AJC, Spinelli LHB, Alves MAO, Ramos PAS, Estevão RA, et al. TENS nas cefaléias Tensionais. 2005 [cited 2011, Mar 3]. Available from: http://www. wgate.com.br/conteudo/medicinaesaude/fisioterapia/eletro/tens_cefaleias.htm
27. Bezerra JCM, Lucena ACT. A utilização da neuroestimulação elétrica transcutânea (TENS) como coadjuvante no tratamento da cefaléia tensional. In: Giona P. Abordagem fisioterapêutica nas cefaleias tensionais através da terapia manual: Cascavel: Unioeste; 2003.

28. Hertling D, Kessler RM. Tratamento de distúrbios musculoesqueléticos comuns: princípios e métodos de fisioterapia. 4. ed. São Paulo: Manole; 2009.

29. Jay GW, Brunson J, Branson SJ. The effectiveness of physical therapy in the treatment of chronic daily headaches. Headache. 1989;29(3):156-62.

30. Hulley SB, Cummings SR., Brower WS, Grady DG, Newman TB. Delineando a pesquisa clínica: uma abordagem epidemiológica. 3. ed. Porto Alegre: Artmed; 2008.

Received: 01/26/2013

Recebido: 26/01/2013

Approved: 02/27/2015

Aprovado: 27/02/2015 